\title{
Aktivitas Antifungi Isolat Actinomycetes dari Sumber Air Panas Ai Sipatn Lotup Sanggau Terhadap Isolat Hortaea werneckii (T1)
}

\author{
Jerliman Manalu ${ }^{1}$, Rahmawati ${ }^{1}$, Novik Nurhidayat ${ }^{2}$ \\ ${ }^{1}$ Program Studi Biologi, Fakultas MIPA, Universitas Tanjungpura, Jl. Prof. Dr. H. Hadari Nawawi, Pontianak, \\ ${ }^{2}$ Bidang Mikrobiologi, Lembaga Ilmu Pengetahuan Indonesia (LIPI), Cibinong, Bogor \\ Email korespondensi : Jerlimanmanalu@gmail.com
}

\begin{abstract}
Pathogenic fungi cause health problems especially the skin infection caused by Hortaea werneckii causes of tinea nigra skin disease. One of the method minimizes the problems and against the growth of Hortaea werneckii can use the active material from Actinomycetes bacteria as the antifungal. This research was to aware the kind of Actinomycetes bacteria that have the most potential as antifungal against the Hortaea werneckii, the effect of metabolic volume composition and incubation time of Actinomycetes bacteria against the Hortaea werneckii (T1). Antifungal activity test used the filtration method of Actinomycetes bacteria with parameters based on incubation time and volume comparison of metabolites concentration. Antifungal activity test of 11 isolates Actinomycetes bacteria produce six isolates Actinomycetes bacteria as the most potential antifungal and the percentage of the effect difference among the treatment against Hortaea werneckii (T1) are Thermoactinomyces sp. (H24) 39,98\%, Thermoactinomyces sp. (H21) 29,11\%, Thermobifida sp. (S311) 21,14\%, Streptomyces sp. (S211) 34,21\%, Actinomadura sp. (S21(2)) 24,70\%, dan Nocardiopsis sp. (H22*1) $33,03 \%$. Bacteria isolate Thermoactinomyces sp. (H24) have a significant percentage of antifungal with an average $97 \%$, as a difference of the effect among treatments are $39,98 \%$. The metabolites produced by Actinomycetes cause Hortaea werneckii (T1) growth to be inhibited and damage cells structure their.
\end{abstract}

Keyword : Hortaea werneckii, Actinomycetes bacteria, Antifungal

\section{PENDAHULUAN}

Tinea nigra merupakan mikosis superfisialis yang dapat menginfeksi kulit, dan salah satu penyebabnya adalah jamur anggota spesies Hortaea werneckii. Penyakit ini dapat menginfeksi lapisan kulit yaitu bagian stratum korneum dari epidermis kulit. Tinea nigra termasuk penyakit asimptomatik karena penderita penyakit ini tidak menyadari gejala apapun dan biasanya menginfeksi telapak tangan maupun telapak kaki (Piliouras et al., 2011). Penyebab penyakit ini karena kurangnya sanitasi pribadi, trauma, dan adanya hiperhidrosis yaitu meningkatnya konsentrasi kelenjar keringat pada tubuh secara berlebihan yang tidak adanya aktivitas olahraga (Rezusta et al., 2010).

Jamur anggota spesies Hortaea werneckii memiliki sinonim atau nama lainnya yaitu PhaeoanneIlomyces werneckii atau Exophiala werneckii, dan Cladosporium werneckii (Bonifaz et al., 2008). Hortaea werneckii menghasilkan dermaticeous yakni dinding selnya mengandung pigmen melanin sehingga memberikan pigmen warna coklat atau hitam pada kulit sehingga sering disebut black yeast. Spesies ini dapat tumbuh dan toleran terhadap kadar salinitas tinggi. Kadar optimum pertumbuhannya berkisar 3-4,5 $\mathrm{M} \mathrm{NaCl}$.
Karakter hifa bersifat hidrofobik dan bersepta (Kejzar et al., 2013).

Bakteri termofilik anggota Actinomycetes dapat menghasilkan senyawa bioaktif yang bersifat antimikroba, sehingga dapat diaplikasikan dalam bidang farmakologi maupun bioteknologi (Limaye $e t$ al., 2017). Bakteri termofilik anggota Actinomycetes menghasilkan berbagai antibiotik seperti tetrasiklin, kloramfenikol, dan rifampisin (Chaudhary et al., 2013). Bakteri anggota Actinomycetes menghasilkan senyawa polyoxins dan nikkomycins yang dapat menghambat sintesis kitin (Aderiye, 2015). Kitin merupakan suatu polisakarida polimer linier yang tersusun oleh monomernya $\beta-1,4-N$ asetilglukosamin. Kitin berfungsi sebagai proteksi organel sel karena komponen penyusun dinding sel fungi (Herdyastuti et al., 2009).

Bakteri termofilik anggota Actinomycetes merupakan bakteri yang dapat hidup pada temperatur suhu 37-65 ${ }^{\circ} \mathrm{C}$ (Kurapova et al., 2012). Agen pengendali yang berpotensi meminimalisasi prevalensi penyakit tinea nigra adalah bakteri termofilik anggota Actinomycetes dari sumber air 
panas Ai Sipatn Lotup di Dusun Peruntan, Desa Sape, Kecamatan Jangkang, Kabupaten Sanggau, Provinsi Kalimantan Barat. Suhu sumber air panas Ai Sipatn Lotup berkisar $55{ }^{\circ} \mathrm{C}$. Beberapa penduduk Dayak Jangkang menggunakan sumber air panas Ai Sipatn Lotup untuk mandi, karena sumber air panas tersebut dipercayai dapat menyembuhkan penyakit kulit. Oleh karena itu, penelitian ini perlu dilakukan untuk bakteri anggota Actinomycetes termofilik yang berpotensi sebagai antifungi untuk menghambat aktivitas mikroba penyebab mikosis superfisialis khususnya anggota spesies Hortaea werneckii

\section{BAHAN DAN METODE}

\section{Waktu dan Tempat Penelitian}

Penelitian dilakukan selama tiga bulan yaitu mulai bulan April hingga Juni 2018. Pengambilan sampel dilakukan di sumber Air Panas Ai Sipatn Lotup, Sanggau, Kalimantan Barat dan probandus yang mengalami gejala tinea nigra. Penelitian dilakukan di Laboratorium Mikrobiologi FMIPA Untan Pontianak, dan Laboratorium Mikrobiologi Kesehatan, Bidang Mikrobiologi, Puslit Biologi Lembaga Imu Pengetahuan Indonesia (LIPI), Cibinong, Bogor.

\section{Bahan}

Bahan-bahan yang digunakan pada penelitian ini antara lain akuades, alkohol $70 \%$, Bacto Agar (merck), etanol $96 \%$, Casein Agar, Ferosulfat Heptahidrat $\left(\mathrm{FeSO}_{4} .7 \mathrm{H}_{2} \mathrm{O}\right)$, glukosa, Hidrogen Peroksida $\left(\mathrm{H}_{2} \mathrm{O}_{2}\right)$, isolat fungi anggota spesies Hortaea werneckii (T1) dan isolat bakteri termofilik anggota Actinomycetes dari sumber air panas $\mathrm{Ai}$ Sipatn Lotup, Kalium Klorida (KCl), Kalium Nitrat $\left(\mathrm{KNO}_{3}\right)$, Kalium Hidrophosphat $\left(\mathrm{K}_{2} \mathrm{HPO}_{4}\right)$, Kalsium Karbonat $\left(\mathrm{CaCO}_{3}\right)$, Kovacs reagent, kristal violet, lugol, lactophenol blue, Magnesium Sulfat Heptahidrat $\left(\mathrm{MgSO}_{4} .7 \mathrm{H}_{2} \mathrm{O}\right)$, maltosa, Malt Extract Agar (MEA) (Merck), Natrium Klorida ( $\mathrm{NaCl})$, Natrium Hidrophosphat $\left(\mathrm{Na}_{2} \mathrm{HPO}_{4}\right)$, Nutrient Agar (NA), Soluble Starch, dan Tryptone.

\section{Prosedur Kerja}

Sterilisasi Alat

Alat-alat yang hendak disterilisasi dan tahan terhadap suhu tinggi dibungkus menggunakan kertas dan plastik, selanjutnya disterilisasi dengan autoklaf selama 15 menit pada suhu $121{ }^{\circ} \mathrm{C}$ dan tekanan $1 \mathrm{~atm}$. Alat-alat yang tidak tahan terhadap suhu tinggi disterilisasi menggunakan alkohol 70\% dan api bunsen.

\section{Pembuatan Media}

Media yang digunakan dalam penelitian ini adalah Starch Casein Agar (10 g Soluble Starch, 0,3 g Casein Agar, 2 g Kalium Nitrat, 2 g Natrium Klorida, $2 \mathrm{~g}$ Dipotasium Hydrogen Fosfat, 0,05 g Magnesium Sulfat Heptahidrat, 0,02 Kalsium Klorida, 0,01 g Fero Sulfat Heptahidrat, dan $18 \mathrm{~g}$ serbuk agar), Nutrient Agar 23 g/l, Nutrient Broth (NB), Malt Extract Agar (MEA) $50 \mathrm{~g} / \mathrm{l}$ dan ditambahkan kloramfenikol $50 \mathrm{mg} / \mathrm{l}$, Malt Extract Broth (MEB). Komposisi bahan ditimbang, kemudian dilarutkan dengan akuades sebanyak $1000 \mathrm{ml}$ diaduk menggunakan batang pengaduk hingga media homogen. Kemudian media dipanaskan hingga mendidih menggunakan microwave, dan mulut wadah media ditutup rapat dengan kapas lalu diberi label media. Setelah dipanaskan, kemudian media disterilisasi menggunakan autoklaf selama 15 menit, pada suhu $121^{\circ} \mathrm{C}$ dan tekanan $1 \mathrm{~atm}$.

\section{Peremajaan Bakteri anggota Actinomycetes}

Isolat bakteri termofilik anggota Actinomycetes yang diperoleh dari hasil isolasi dari sumber air panas Ai Sipatn Lotup diremajakan kembali menggunakan metode kuadran dengan cara penggoresan (streak plate pada media Starch Casein Agar (SCA) dan NA, selanjutnya diinkubasikan pada suhu $50^{\circ} \mathrm{C}$ selama $24-72$ jam sampai terlihat koloni-koloni tunggal yang tumbuh.

Peremajaan isolat Hortaea werneckii (T1)

Isolat jamur anggota spesies Hortaea weneckii (T1) diinokulasikan kembali dengan jarum ose ke media agar miring, kemudian diinkubasikan pada suhu 30 ${ }^{\circ} \mathrm{C}$ selama 3-5 hari hingga diperoleh pertumbuhan yang normal (Brooks et al., 2005).

\section{Pembuatan Suspensi Isolat Bakteri Anggota Actinomycetes}

Koloni bakteri anggota Actinomycetes diinokulasikan ke dalam media cair NB. Kekeruhan suspensi bakteri anggota Actinomycetes diukur menggunakan alat microplate reader dengan panjang gelombang $530 \mathrm{~nm}$.

\section{Pembuatan Suspensi Isolat Jamur Hortaea werneckii (T1)}

Koloni fungi lalu disuspensikan ke dalam media MEB. Kekeruhan suspensi mikroba uji diukur menggunakan alat microplate reader dengan panjang gelombang $530 \mathrm{~nm}$ (Depkes, 1995). 
Uji Antifungi Bakteri Termofilik Anggota Actinomycetes Terhadap Isolat Jamur Anggota Spesies Hortaea werneckii (T1).

Uji antifungi dilakukan dengan dengan metode filtrasi. Optical density (OD) suspensi isolat bakteri anggota Actinomycetes diukur menggunakan microplate reader, kemudian suspensi isolat bakteri tersebut difiltrasi menggunakan filter $0.2 \mu \mathrm{m}$. Filtrat yang diperoleh diambil dan dicampur dengan suspensi Hortaea werneckii (T1) dengan perbandingan konsentrasi volume 1:1 (100 $\mu 1 \mathrm{~T} 1$ : $100 \mu \mathrm{l}$ filtrat isolat Actinomycetes $) ; 1,33: 1(100 \mu \mathrm{l}$ $\mathrm{T} 1: 75 \mu \mathrm{l}$ filtrat Actinomycetes $) ; 2: 1(100 \mu 1 \mathrm{~T} 1: 50$ $\mu 1$ filtrat isolat Actinomycetes); 4:1 (100 $\mu \mathrm{l} \mathrm{T1}: 25$ $\mu \mathrm{l}$ filtrat Actinomycetes) dan ditambahkan media MEB sebanyak $1 \mathrm{ml}$ untuk pertumbuhan Hortaea werneckii (T1), kemudian diukur OD sebelum diinkubasi untuk mengamati perubahan pertumbuhan isolat anggota spesies Hortaea werneckii (T1). Kontrol negatif yaitu isolat anggota spesies Hortaea werneckii (T1) yang ditumbuhan pada media MEB sebanyak $1 \mathrm{ml}$ dan tidak diberi perlakuan filtrat isolat Actinomycetes, sedangkan kontrol positif yang digunakan yaitu ketokenazol $2 \%$. Selanjutnya diinkubasi selama 20, 44, dan 68 jam kemudian diukur OD aktivitas antifungi bakteri anggota Actinomycetes terhadap Hortaea werneckii (T1).

\section{Pengukuran Aktivitas Antifungi Isolat Bakteri Termofilik Anggota Actinomycetes Terhadap Hortaea werneckii (T1)}

Filtrat bakteri anggota Actinomycetes yang dicampur dengan suspensi isolat Hortaea werneckii (T1) dan ditambahkan media $1 \mathrm{ml}$ pada eppendorf untuk uji aktivitas antifungi, kemudian dihomogenkan. Setelah homogen lalu diambil sebanyak $200 \mu \mathrm{l}$ menggunakan mikropipet dan dimasukkan ke dalam microplate. Kemudian diukur OD suspensi pada waktu inkubasi selama 20 jam, 44 jam, dan 68 jam menggunakan microplate reader dan dibandingkan dengan kontrol negatif.
Perhitungan persentase antifungi menggunakan rumus:

$\%$ Antifungi : $\frac{\text { Kontrol negatif }- \text { Perlakuan } \times 100 \%}{\text { Kontrol negatif }}$

\section{Analisis dan Penyajian Data}

Data hasil penelitian ini dianalisis secara deskriptif dengan menampilkan hasil berupa gambar, tabel, dan deskripsi. Persentase antifungi dianalisis menggunakan Rancangan Acak Lengkap (RAL) Faktorial dengan program SPSS 18 berdasarkan data jenis isolat bakteri, komposisi volume perbandingan, dan waktu inkubasi. Apabila data yang diperoleh hasilnya berbeda nyata, maka dilanjutkan dengan uji Tukey pada taraf signifikan $5 \%$ (Sujarweni, 2012).

\section{HASIL DAN PEMBAHASAN}

\section{Hasil}

Jumlah isolat bakteri anggota Actinomycetes yang diskrining uji aktivitas antifungi berdasarkan perbandingan volume dan waktu inkubasi yaitu 11 isolat (isolat S211, H12, H2232, S311, S311A, S31, H24, H22*1, H21, H11, dan S21(2)). Isolat bakteri anggota Actinomycetes penghasil aktivitas antifungi dan terdapat pengaruh perlakuan berdasarkan analisa RAL faktorial terhadap isolat Hortaea werneckii (T1) yaitu isolat bakteri Thermoactinomyces sp. (H21), Thermoactinomyces sp. (H24), Thermobifida sp. (S311), Streptomyces sp. (S211), Actinomadura sp. (S21(2), dan Nocardiopsis sp. $(\mathrm{H} 22 * 1)$. Kontrol negatif yang digunakan sebagai pembanding yaitu isolat anggota spesies Hortaea werneckii (T1) yang diinokulasi pada media MEB sebanyak $1 \mathrm{ml}$ tanpa diberi perlakuan lain. Kontrol positif yang digunakan sebagai pembanding yaitu ketokenazol $2 \%$ karena masyarakat sering menggunakannya sebagai obat topikal untuk menyembuhkan infeksi kulit yang disebabkan oleh jamur.

Hasil uji antifungi menunjukkan bahwa pada suhu $50{ }^{\circ} \mathrm{C}$ selama $20 \mathrm{jam}, 44 \mathrm{jam}$, dan 68 jam dengan komposisi perbandingan volume $1: 1(100 \mu \mathrm{l}: 100$ $\mu \mathrm{l}), 1,33: 1(100 \mu \mathrm{l}: 75 \mu \mathrm{l}), 2: 1(100 \mu \mathrm{l}: 50 \mu \mathrm{l})$, dan 4:1 (100 $\mu 1: 25 \mu \mathrm{l})$ dapat dilihat pada Gambar 1-4. 


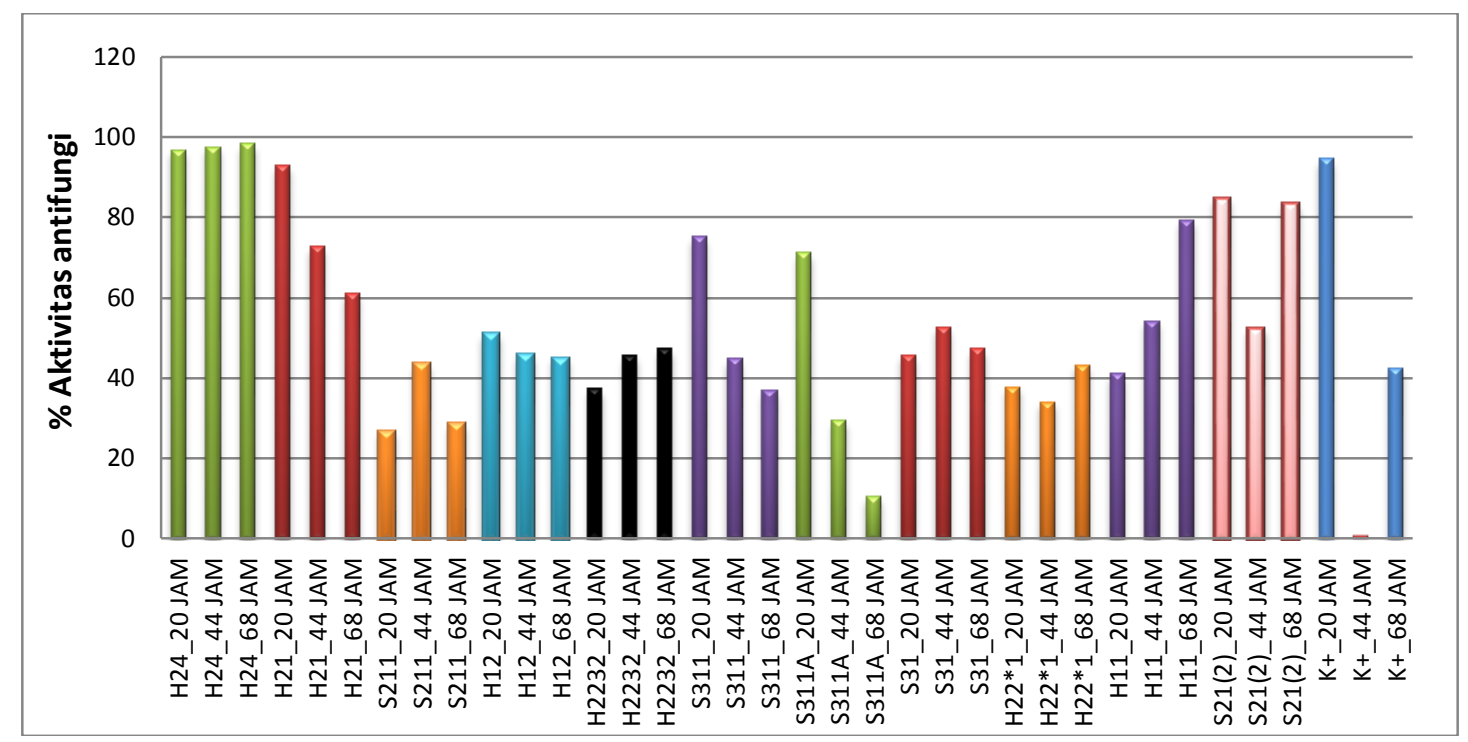

Gambar 1. Grafik persentase antifungi isolat bakteri anggota Actinomycetes terhadap H. werneckii berdasarkan komposisi perbandingan volume $1: 1(100 \mu \mathrm{l}: 100 \mu \mathrm{l})$

Hasil uji antifungi menunjukkan bahwa pada suhu $50{ }^{\circ} \mathrm{C}$ selama $20 \mathrm{jam}, 44 \mathrm{jam}$, dan 68 jam dengan komposisi perbandingan volume 1:1 menunjukkan terdapat isolat bakteri yang bersifat fungisidal dan fungistatik karena semua isolat bakteri menghasilkan aktivitas antifungi. Isolat bakteri yang bersifat fungisidal yaitu isolat H21, S311, dan
S311A. Isolat yang memiliki aktivitas fungisidal signifikan yaitu isolat $\mathrm{H} 21$ dengan persentase 92,96\% (20 jam), 72,77\% (44 jam), dan 72,71\% (68 jam). Isolat yang memiliki aktivitas fungistatik signifikan yaitu isolat bakteri $\mathrm{H} 24$ dengan persentase 96,79\% (20 jam), 97,39\% (44 jam), dan 98,18\% (68 jam) (Gambar 1).

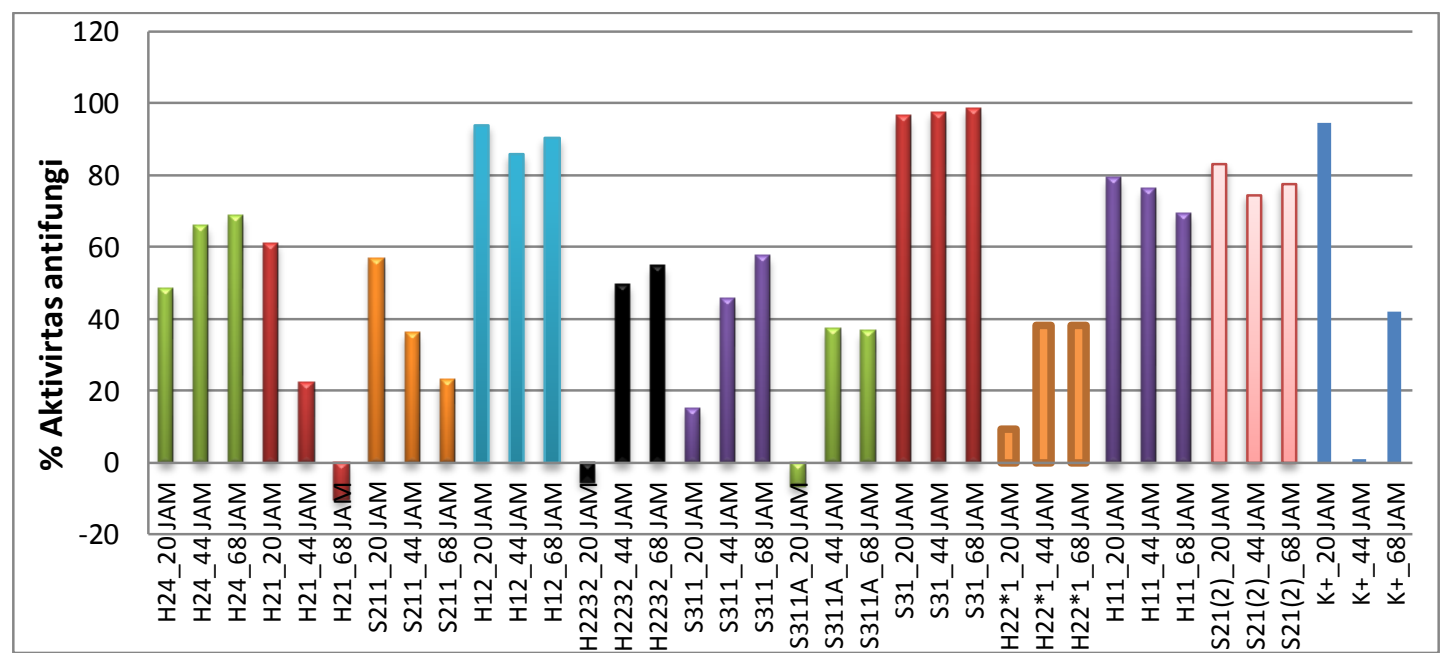

Gambar 2. Grafik persentase antifungi isolat bakteri anggota Actinomycetes terhadap H. werneckii berdasarkan komposisi perbandingan volume $1,33: 1(100 \mu \mathrm{l}: 75 \mu \mathrm{l})$

Isolat bakteri S31 memiliki nilai rata-rata persentase pada waktu inkubasi selama 20 jam $(93,90 \%), 44$ jam $(85,77 \%)$, dan 68 jam $(90,41 \%)$. Isolat bakteri S31 memiliki nilai rata-rata persentase antifungi pada waktu inkubasi selama 20 jam $(96,46 \%), 44$ jam (97,62\%), dan 68 jam $(98,60 \%)$. Berdasarkan grafik menunjukkan bahwa isolat bakteri anggota
Actinomycetes memiliki antifungi bersifat fungisidal dan fungistatik. Isolat bakteri yang bersifat fungisidal yaitu isolat $\mathrm{H} 21$, sedangkan isolat bakteri bersifat fungistatik yaitu $\mathrm{H} 24, \mathrm{H} 2232$, S311, S311A, S211, H12, S31, H22*1, H11, S21(2), dan kontrol positif (Gambar 2). 


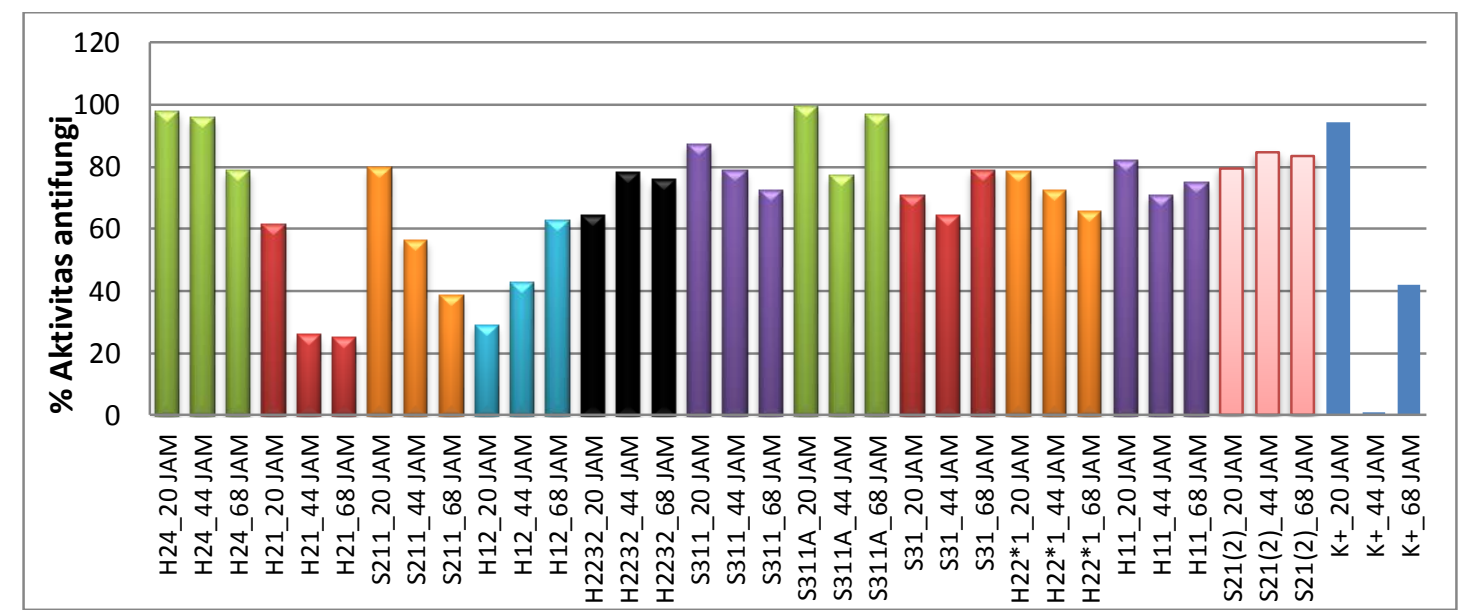

Gambar 3. Grafik persentase antifungi isolat bakteri anggota Actinomycetes terhadap H. werneckii berdasarkan komposisi perbandingan volume $2: 1(100 \mu \mathrm{l}: 50 \mu \mathrm{l})$

Hasil uji antifungi dengan perbandingan volume 2:1 menunjukkan bahwa nilai persentase antifungi tertinggi yaitu isolat bakteri $\mathrm{H} 24$ dan S311 A. Isolat bakteri H24 memiliki nilai rata-rata persentase antifungi pada waktu inkubasi selama 20 jam (97,93\%), 44 jam $(95,82 \%)$, dan 68 jam $(78,77 \%)$. Isolat bakteri S311A memiliki nilai rata-rata persentase antifungi pada waktu inkubasi selama 20 jam (97,93\%), 44 jam $(95,82 \%)$, dan 68 jam $(78,77 \%)$. Berdasarkan grafik tidak menunjukkan adanya antifungi bersifat fungisidal melainkan bersifat fungistatik. Hal ini dikarenakan bakteri tersebut hanya mampu membunuh pada konsentrasi atau volume yang tinggi (Gambar 3).

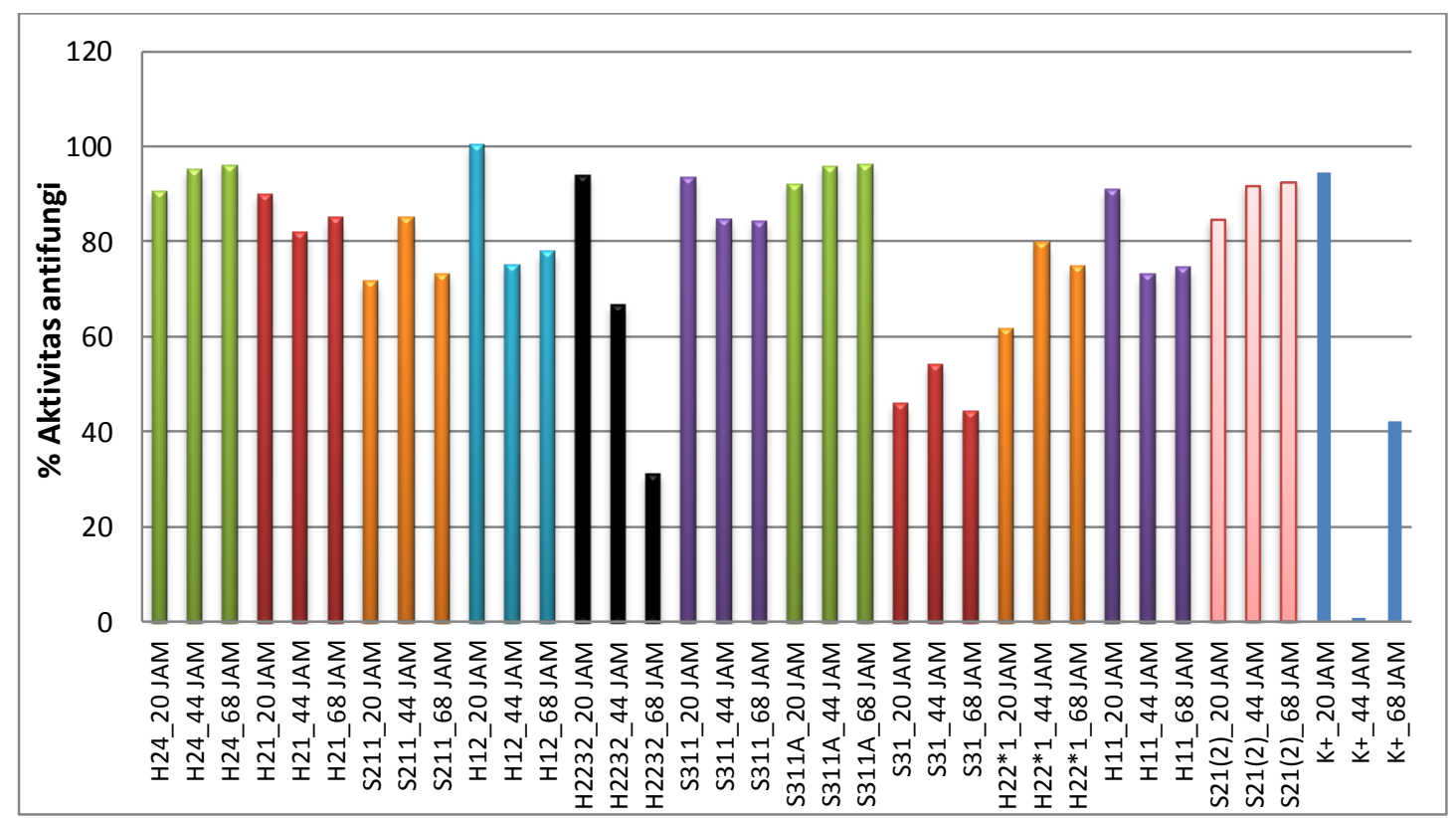

Gambar 4. Grafik persentase antifungi isolat bakteri anggota Actinomycetes terhadap H. werneckii berdasarkan komposisi perbandingan volume 4:1 $(100 \mu \mathrm{l}: 25 \mu \mathrm{l})$

Hasil uji antifungi yang diinkubasi pada suhu $50{ }^{\circ} \mathrm{C}$ selama 20 jam, 44 jam, dan 68 jam dengan perbandingan volume 4:1 menunjukkan bahwa nilai persentase antifungi tertinggi yaitu isolat bakteri H24 dan S311A. Isolat bakteri H24 memiliki nilai rata-rata persentase antifungi pada waktu inkubasi selama 20 jam $(90,55 \%), 44$ jam $(95,12 \%)$, dan 68 jam $(96 \%)$. Isolat bakteri S311 A memiliki nilai ratarata persentase antifungi pada waktu inkubasi selama 20 jam $(92,05,55 \%), 44$ jam $(95,79 \%)$, dan
68 jam (96,32\%). Berdasarkan grafik tidak menunjukkan adanya antifungi bersifat fungisidal melainkan bersifat fungistatik. (Gambar 4). Hasil uji antifungi menunjukkan bahwa dengan perlakuan keseluruhan komposisi perbandingan volume dari RAL Faktorial terdapat perbedaan atau pengaruh perlakuan metabolit isolat bakteri $\mathrm{H} 24, \mathrm{H} 21, \mathrm{~S} 311$, H22*1, S211, S21(2), dan kontrol positif (ketokenazol 2\%) berdasarkan komposisi volume 
maupun waktu inkubasi terhadap antifungi Hortaea werneckii (T1).

\section{Pembahasan}

Pengujian antifungi isolat bakteri anggota Actinomycetes terhadap pertumbuhan anggota spesies Hotaea werneckii (T1) dilakukan dengan memberikan perbedaan varisasi komposisi volume 1:1 $(100 \mu \mathrm{l}: 100 \mu \mathrm{l}), 1,33: 1(100 \mu \mathrm{l}: 75 \mu \mathrm{l}), 2: 1$ (100 $\mu \mathrm{l}: 50 \mu \mathrm{l})$, dan 4:1 (100 $\mu \mathrm{l}: 25 \mu \mathrm{l})$, sedangkan varisasi waktu inkubasi selama 20 jam, 44 jam, dan 68 jam. Kontrol negatif yang digunakan sebagai pembanding persentase antifungi menggunkan isolat anggota spesies Hortaea werneckii (T1) yang diinokulasikan pada media MEB sebanyak $1 \mathrm{ml}$ tanpa diberi perlakuan lain, sehingga pertumbuhannya relatif berbeda jika dibandingkan dengan perlakuan filtrat bakteri Actinomycetes. Hal ini disebabkan media yang digunakan tidak mengandung antifungi sehingga pertumbuhan isolat jamur anggota spesies Hortaea werneckii (T1) lebih optimal. Menurut Singh et al. (2014), kontrol negatif berfungsi sebagai pembanding perlakuan karena pada media kontrol negatif tidak ada senyawa yang menghambat pertumbuhan mikroba uji.

Kontrol positif yang digunakan sebagai pembanding yaitu ketokenazol 2\%. Menurut Anggarini et al. (2015), ketokonazol merupakan derivat imidazol dioxolane sintetis yang memiliki efek antifungi yang berpotensi dan sensitif terhadap mikosis superfisialis. Menurut Najmuddin et al. (2010), ketokonazol bekerja spesifik terhadap sel fungi dengan menghambat enzim sitokrom P450 yang terlibat dalam jalur biosintesis sterol dan akan mengubah lanasterol menjadi ergosterol pada membran sel fungi.

Isolat yang memiliki persentase antifungi berbeda secara signifikan berdasarkan komposisi perbandingan volume dan waktu kontak yang berbeda. Komposisi perbandingan volume 1:1 memiliki nilai aktivitas antifungi relatif tinggi jika dibandingkan dengan perbandingan volume (1,33:1, 2:1, dan 4:1) karena komposisi volume mempengaruhi pertumbuhan mikroba uji. Hal ini menunjukkan bahwa semakin tinggi konsentrasi atau komposisi perbandingan volume antifungi maka semakin rendah pertumbuhan isolat anggota spesies Hortaea werneckii (T1). Menurut Pelzcar (1988), semakin tinggi konsentrasi suatu bahan antifungi maka aktivitas antifungi akan semakin tinggi. Adanya aktivitas antifungi dipengaruhi tingginya toksisitas yang dihasilkan oleh bakteri anggota Actinomycetes, dan kecepatan suatu zat yang diabsorbsi anggota spesies Hortaea werneckii sehingga pertumbuhannya terhambat.

Persentase antifungi tiap isolat dan kontrol positif menunjukkan terjadi penurunan dan peningkatan berdasarkan waktu inkubasi selama 20 jam, 44 jam, dan 68 jam seperti pada grafik hasil aktivitas antifungi. Adanya penurunan persentase antifungi disebabkan isolat anggota spesies Hortaea werneckii (T1) memiliki sensitivitas yang rendah terhadap antifungi yang dihasilkan oleh anggota Actinomycetes. Menurut Hussein et al. (2011), minimnya sensitivitas jamur terhadap antifungi menunjukkan bahwa jamur tersebut memiliki aktivitas pertumbuhan yang lambat, sehingga metabolit antifungi dapat menghambat pertumbuhan mikroba uji dengan minimum. Sensitivitas antifungi berdasarkan konsentrasi hambat minimum seperti komposisi perbandingan volume 4:1 dapat menghambat isolat jamur anggota spesies Hortaea werneckii (T1). Antifungi yang dihasilkan bakteri dapat meningkatkan aktivitasnya apabila konsentrasi ditingkatkan dari konsentrasi atau komposisi minimum mikroba uji, sehingga sifat fungistatik dapat berubah menjadi fungisidal. Menurut Ong et al.(2018), suatu bakteri dikatakan mempunyai aktivitas yang tinggi bila konsentrasi minimum terjadi pada kadar rendah tetapi mempunyai sifat fungisidal atau fungistatik yang tinggi. Sifat fungisidal atau fungistatik dipengaruhi oleh konsentrasi uji dan waktu kontak pada mikroba uji. Sifat fungisidal yaitu membunuh mikroba uji secara irreversibel, sedangkan sifat fungistatik yaitu menghambat mikroba uji secara reversibel atau sementara. Menurut Mizuhara et al. (2011), jika senyawa antifungi yang dihasilkan oleh bakteri tidak maksimal maka fungsi sebagai fungisidal tidak akan bereaksi tetapi dapat bersifat sebagai fungistatik. Perlakuan tidak bersifat fungisidal dikarenakan konsentrasi metabolit yang dihasilkan oleh bakteri tidak optimal.

Waktu inkubasi 44 jam dan 68 jam menunjukkan bahwa metabolit yang dihasilkan isolat bakteri anggota Actinomycetes pada perlakuan 1:1 (isolat $\mathrm{H} 2232, \mathrm{H} 11$ ), 1,33:1 (isolat $\mathrm{H} 24, \mathrm{H} 2232, \mathrm{~S} 311$, S31, H222*1), 2:1 (isolat H12), dan perlakuan 4:1 (isolat H12 dan S21(2)) berinteraksi lebih lama sehingga lebih banyak koloni isolat jamur anggota spesies Hortaea weneckii (T1) yang dihambat dibandingkan dengan waktu inkubasi 20 jam, dikarenakan antifungi yang dihasilkan bakteri anggota Actinomycetes bersifat fungistatik. Menurut Managamuri (2017), semakin lama kontak 
atau waktu inkubasi maka semakin berkurang jumlah organisme mikroba uji karena meningkatknya efektivitas metabolit yang dihasilkan bakteri anggota Actinomycetes

Hasil yang diperoleh menunjukkan terdapat pengaruh waktu inkubasi terhadap aktivitas antifungi yaitu waktu inkubasi selama 20 jam aktivitasnya lebih tinggi dari waktu inkubasi selama 44 jam dan mengalami kembali peningkatan aktivitas antifungi pada waktu inkubasi selama 68 jam. Hal ini disebabkan antifungi yang dihasilkan oleh isolat bakteri anggota Actinomycetes hanya dapat menghambat pertumbuhan Hortaea werneckii (T1) yang bersifat fungistatik berdasarkan komposisi perbandingan volume minimum dan maksimum. Keberadaan zat fungistatik pada isolat bakteri anggota Actinomycetes tidak langsung membunuh sel, sehingga sel jamur tidak sensitif dan dapat tumbuh kembali akibat berkurangnya zat fungistatik. Menurut Ningsih et al. (2017), aktivitas antifungi menurun dipengaruhi oleh konsentrasi zat aktif antifungi, sebab semakin tinggi konsentrasi suatu bahan antimikroba maka aktivitas mikrobanya semakin besar. Menurut Dewi (2009), pengujian aktivitas antifungi tergantung pada kandungan komponen kimia yang berfungsi sebagai antifungi yang terdapat dalam ekstrak tersebut.

Hasil yang diperoleh menunjukkan terdapat pengaruh waktu inkubasi terhadap aktivitas antifungi yang berbanding terbalik seperti pada waktu inkubasi 20 jam aktivitasnya lebih tinggi dari 44 jam dan 68 jam. Hal ini disebabkan bakteri tersebut bersifat fungisidal yang langsung mengalami kontak dengan sel fungi. Menurut Han et al. (2018), durasi kontak antifungi juga dipengaruhi oleh afinitas antifungi pada membran mikroba untuk mengikat asam nukleat mikroba uji. Ketika mengalami fase kematian yakni membran tidak utuh tetapi penetrasi dapat merusak organel sel. Adanya antifungi dapat menimbulkan abnormalitas morfologi jamur dan menghambat pertumbuhan miselium. Perubahan tersebut karena adanya dinding sel jamur yang dapat memproteksi senyawa atau metabolit yang bersifat toksik, sehingga akan menekan tekanan osmotik dinding sel jamur.

Hasil uji beda nyata berdasarkan analisa RAL faktorial isolat bakteri Thermoactinomyces sp. (H21), Thermoactinomyces sp. (H24), Thermobifida sp. (S311), Streptomyces sp. (S211), Actinomadura sp. (S21(2), dan Nocardiopsis sp. $(\mathrm{H} 22 * 1)$ memiliki senyawa antifungi yang berbeda untuk menghambat pertumbuhan jamur. Menurut Arenz \& Wilson (2016), bakteri anggota genus Thermoactinomyces menghasilkan senyawa antibiotik berupa senyawa aromatik yaitu anthracenopyranone dari struktur antibiotik thermorubin. Senyawa ini berfungsi untuk menghambat aktivitas aldose reduktase jamur sehingga dapat mengikat ribosom. Interaksi metabolit dengan ribosom akan terjadi pemisahan sub unit. Hal ini akan mengikat dan menghambat tRNA selama proses elongasi pada translasi. Menurut Teta et al. (2017), bakteri anggota spesies Thermoactinomyces sp. juga menghasilkan senyawa antibiotik berupa senyawa aromatik yaitu Cyclic Hexapeptides thermoactinoamide A-F yang berfungsi menghambat mikroba lipofilik. Shivlata \& Satyanarayana (2015) menyatakan bahwa mikroba lipofilik merupakan mikroba yang dapat berkembang biak dalam lipid. Bakteri anggota spesies Thermobifida alba dapat menghasilkan senyawa topostatin dan isoaurostatin yang berfungsi sebagai antimikroba. Senyawa ini bersifat inhibitor terhadap DNA topoimerase dan mengganggu sel saat proses replikasi, transkripsi, dan translasi.

Bakteri anggota Streptomyces sp. menghasilkan senyawa polyoxins dan nikkomycins yang dapat menghambat sintesis kitin. Senyawa ini efektif dan spesifik menghambat kinerja enzim kitinase. Polimer kitin disintesis oleh membrane plasma dan berasosiasi dengan protein yang menerima substrat dari sitosol dan menekan polimer kitin di dinding sel (Aderiye et al., 2015).

Senyawa antifungi yang dihasilkan oleh bakteri anggota genus Actinomadura adalah polycyclic tetrahydroxanthone berupa senyawa aromatik sebagai toksin untuk menghambat aktivitas Curvularia lunata, Alternaria brassicicola, dan Colletotrichum capsici (Bunyapaiboonsri et al., 2017). Actinomadura menghasilkan metabolit sekunder berupa antifungi yaitu pradimicins A-C. Senyawa lain yang dihasilkan yaitu adxanthromicin, azanthromicin, oxanthromicin, dan adxanthromicin (Bunbamrunga et asl., 2018).

Bakteri anggota genus Nocardiopsis memiliki senyawa antifungi seperti p-terphenyl dan novobiocin. Senyawa ini berperan sebagai antifungi terhadap anggota genus Fusarium dan Candida albicans. Senyawa $p$-terphenyl merupakan senyawa hidrokarbon aromatik yang terdiri tiga cincin phenil. Senyawa ini dapat mengikat ATP dan mendegradasi protein (Tian et al., 2013). Nocardiopsis menghasilkan senyawa antifungi, 
antibakteri, antibiofilm seperti phenazine yang terdiri dari ikatan 2-amino-2-deoxyisochorismate synthase. Senyawa ini dapat mengubah struktur sel miselium jamur patogen (Sabu et al., 2017). Senyawa Fluvirucin merupakan senyawa antimikroba terhadap patogen. Senyawa ini akan menghambat phosphatidylinositol spesifik fosfolipase pada jamur (Leutou et al., 2018).

\section{DAFTAR PUSTAKA}

Aderiye, BI \& Oluwole, OA, 2015, 'Antifungal Agents That Target Fungal Cell Wall Components: A Review', Agricultural and Biological Sciences Journal, Vol.1, No.5, hal. 206-216

Anggarini, R, Sukanto, DH, Astari, L \& Endraswari, DP, 2015, 'Uji Kepekaan Griseofulvin, Ketokonasol, Itrakonasol, dan Terbinafin terhadap Spesies Dermatofit dengan Metode Mikrodilusi', Berkala Ilmu Kesehatan Kulit dan Kelamin, Vol.27, No.1, hal. 55-62

Arenz, S \& Wilson, DN, 2016, 'Blast from the Past: Reassessing Forgotten Translation Inhibitors, Antibiotic Selectivity, and Resistance Mechanisms to Aid Drug Development', Molecular Cell, Vol.61, No.1, hal. 1-12

Bonifaz, A, Badali, H, de-Hoog, SG, 2008, 'Tinea Nigra by Hortaea werneckii, a Report of 22 Cases From Mexico', Stud Mycol, Vol.61, No.7, hal.77-82

Brooks, Geo, F, Janet, BS, Stephen, AM, Jawetz, Melnick \& Adelberg's, 2005, Medical Microbiology, Penerbit EGC, Jakarta.

Bunyapaiboonsri, T, Yoiprommarat, S, Suriyachadkun, C, Supothina, S, Chanthaket, R, Chutrakul, C \& Vichai, V, 2017, 'Actinomadurone, a polycyclic tetrahydroxanthone from Actinomadura sp. BCC 35430', Tetrahedron Letters, Vol.58, No.1, hal. 3223-3225

Chaudhary, SH, Yadav, J, Shrivastava, RA, Singh, H, Singh, KA \& Gopalan, N, 2013, 'Antibacterial Activity of Actinomycetes Isolated from Different Soil Samples of Sheopur (a City of Central India)', Journal of Advanced Pharmaceutical Technology \& Research, Vol.4, No.2, hal. 118-123

Dewi, RC, 2009, Uji Aktivitas Antijamur Ekstrak Buah Pare Belut (Trichosanthes anguina L.), Skripsi, Fakultas Matematika dan Ilmu Pengetahuan Alam Universitas Sebelas Maret, Surakarta

Han, Y, Zhao, J, Zhang, B, Shen, Q, Shang, Q \& Li, P, 2018, 'Effect of a Novel Antifungal Peptide P852 on Cell Morphology and Membrane Permeabilityof Fusarium oxysporum', BBA-Biomembranes, hal. 1-24, Doi:org/10.1016/j.bbamem.2018.10.018
Herdyastuti, N, Raharjo, JT, Mudasir \& Matsjeh, S, 2009, 'Kitinase dan Mikroorganisme Kitinolitik: Isolasi, Karakterisasi dan Manfaatnya', Indo. J. Chem, Vol.9, No.1, hal.37-47

Hussein, AMS, Shedeed, NA, Abdel-Kalek, HH \& ElDin, HAS, 2011, 'Antioxidative, Antibacterial and Antifungal Activities of Tea Infusions from Berry Leaves, Carob and Doum', Pol. J. Food Nutr. Sci, Vol.61, No.3, hal. 201-209.

Kurapova, AJ, Zenova, GM, Sudnitsyn, II, Kizilova, AK, Manucharova, NA, Norovsuren, Z \& Zvyagintsev, DG, 2012, 'Thermotolerant and Thermophilic Actinomycetes from Soils of Mongolia Desert Steppe Zone', MICROBIOLOGY, Vol. 81, No.1, hal. 98-108

Limaye, L, Patil, R, Ranadive, P \& Kamath, G, 2017, 'Application of Potent Actinomycete Strains for Bio-Degradation of Domestic Agro-Waste by Composting and Treatment of Pulp-Paper Mill Effluent', Advances in Microbiology, Vol.7, No.1, hal. 94-108

Managamuri, U, Vijayalakshmi, M, Poda, S, Ganduri, VKRS \& Rajulapati, BS, 2017 'Optimization of Operating Conditions for the Production of Enhanced Antifungal Metabolites from Streptomonospora arabica VSM 25 by Full Factorial Design', J Young Pharm, Vol.9, No.3, hal.399-409

Mizuhara, N, Kuroda, M, Ogita, A, Tanaka, T, Usuki, Y \& Fujita, K, 2011, 'Antifungal Thiopeptide Cyclothiazomycin B1 Exhibits Growth Inhibition Accompanying Morphological Changes Via Binding to Fungal Cell Wall Chitin', Bioorganic \& Medicinal Chemistry, Vol.19, No.1

Najmuddin, M, Khan, T, Mohsin, A.A, Shellar, S \& Patel, V, 2010, Enhancement of Dissolution Rate of Ketoconazole by Solid Dispesion Tehnique.International Journal of Pharmacy and Pharmaceutical Sciences, Vol.2, No.3, hal. 132136.

Ningsih, DR, Zusfahair \& Mantari, D, 2017, 'Ekstrak Daun Mangga (Mangifera indica L.) Sebagai Antijamur Terhadap Jamur Candida albicans dan Identifikasi Golongan Senyawanya, Jurnal Kimia Riset, Vol2, No.1, hal.61-68

Ong, Cw, Chan, YS, Khoo, KS, Ong, HC \& Sit, NW, 2018, 'Antifungal and Cytotoxic Activities Of Extracts Obtained From Underutilised Edible Tropical Fruits', Asian Pacific Journal of Tropical Biomedicine, Vol.1, No.6, hal. 313-319

Pelzcar, MJ \& Chan, ECS, 1988, Dasar-Dasar Mikrobiologi, Universitas Indonesia, Jakarta 
Piliouras, P, Allison, S, Rosendahl, C, Buettner, GP \& Weedon, D, 2011, 'Dermoscopy Improves Diagnosis of Tinea Nigra: A Study Of 50 Cases', Australian Journal of Dermatology', Vol.52, No.1, Hal.19-194

Rezusta, A, Gilaberte, Betran, A, Gene, J, Querol, I, Arias, M \& Revillo, JM, 2010, 'Tinea nigra: a Rare Imported Infection', JEADV, Vol.24, No.1, hal. 89-91

Sabu, R, Soumya, KR \& Radhakrishnan, EK, 2017, 'Endophytic Nocardiopsis sp. from Zingiber officinale with Both Antiphytopathogenic Mechanisms and Antibiofilm Activity Against Clinical Isolates, 3 Biotech, Vol.7, No.115, Hal.113

Shivlata, L \& Satyanarayana, T, 2015, 'Thermophilic and alkaliphilic Actinobacteria: Biology and Potential Applications', Frontiers in Microbiology, Vol.6, No. 1014 Singh, LS, Sharma, H, Talukdar, NC, 2014, Production of Potent Antimicrobial Agent by Actinomycete, Streptomyces sannanensis strain SU118 Isolated From Phoomdi in Loktak Lake of Manipur, India, BMC Microbiology, Vol.14, No.278, hal.1-13., hal.1-29

Sujarweni, WV, 2012, SPSS untuk Paramedis, Gava Media, Yogyakarta.

Teta, R, Marteinsson, VT, Longeon, A, Klonowski, AM, Groben, R, Bourguet-Kondracki, M, Costantino, V \& Mangoni, A, 2017, 'Thermoactinoamide A, an Antibiotic Lipophilic Cyclopeptide from the Icelandic Thermophilic Bacterium Thermoactinomyces vulgaris', Journal of Natural Products, Vol.1, No.80, Hal.2530-2535

Tian, S, Pu, X, Luo, G, Zhao, L, Xu, L, Li, W \& Luo, Y, 2013, 'Isolation and Characterization of New pTerphenyls with Antifungal, Antibacterial, and Antioxidant Activities from Halophilic Actinomycete Nocardiopsis gilva YIM 90087', Journal of Agricultural and Food Chemistry, Vol.61, No.1, hal. 3006-3012 